\title{
Aortic thrombosis in a patient with a late diagnosis of Behcet's disease
}

\section{Trombose aórtica em paciente com diagnóstico tardio de Doença de Behçet}

Ana Bittencourt Detanico', Marcelo Luiz Brandão', Ly de Freitas Fernandes', Carolina Parreira Ribeiro Camelo', Juliano Ricardo Santana dos Santos ${ }^{1}$

\begin{abstract}
Behcet's disease is form of systemic vasculitis of unknown etiology. One surprising feature is that arterial involvement is less common in this disease than venous forms, accounting for 1 to $7 \%$ of patients. In 7 to $30 \%$ of cases the vascular symptoms precede the clinical diagnosis of Behcet. We describe the case of a patient with Thromboangiitis Obliterans who was treated with lumbar sympathectomy and an aortobiiliac bypass. Around 1 year later he was diagnosed with Behcet's disease after presenting with oral ulcers, genital ulcers and scaling lesions on the hands.
\end{abstract}

Keywords: Behcet Syndrome; arteritis; peripheral arterial disease.

\begin{abstract}
Resumo
A Doença de Behçet é uma vasculite sistêmica de etiologia desconhecida. O inusitado é que o acometimento arterial nesta doença é menos comum que o venoso, correspondendo a 1 a $7 \%$ dos pacientes. Já os sintomas vasculares precedem o diagnóstico clínico de Behçet em 7 a 30\%. Relatamos o caso de um paciente portador de Tromboangeíte Obliterante que foi submetido a simpatectomia lombar e derivação aorto-bi-ilíaca. Após cerca de um ano, diagnosticou-se Doença de Behçet, devido a quadro clínico de úlceras orais, genitais e lesões descamativas nas mãos.
\end{abstract}

Palavras-chave: Síndrome de Behçet; arterite; doença arterial periférica. 


\section{INTRODUCTION}

Behcet's disease is a multi-systemic form of vasculitis of unknown etiology that typically affects young adults aged 20 to 40, especially populations from the Mediterranean Region and Japanese people. It is characterized by recurrent oral ulcers and systemic manifestations including genital ulcers, cutaneous lesions, arthropathy and ocular, neurological or vascular disease. ${ }^{1-6}$

Vascular involvement occurs in 23 to $50 \%$ of patients and is more common among male patients and young patients, with onset commonly occurring later on in the course of the disease. ${ }^{1,-13}$ Behcet's disease can affect vessels of all calibers (small, medium and large) and affects both venous and arterial systems, with arterial involvement less common. The disease has a wide spectrum of manifestations, ranging from venous and arterial thrombosis to aortic and visceral aneurysms. ${ }^{1,12}$

\section{CASE DESCRIPTION}

A male patient presented at the vascular surgery service at the Universidade Federal de Goiás Hospital das Clínicas in 2008, at the age of 34, complaining of intermittent claudication in lower limbs. The patient had a history of smoking for 20 years, without comorbidities, and so he was diagnosed with Thromboangiitis Obliterans and prescribed clinical treatment. In 2009, claudication worsened in the left lower limb. Arteriography showed occlusion of the anterior and posterior tibial arteries. Since the occluded segment was extensive and there was no distal bed for grafting, a left lumbar sympathectomy was performed. In 2012, the ptient presented at emergency, with pain at rest, unchanging cyanosis of toes and a trophic lesion on the left lower limb. Aortography revealed distal aortic occlusion (Figure 1), and an aortobiiliac graft was constructed successfully.

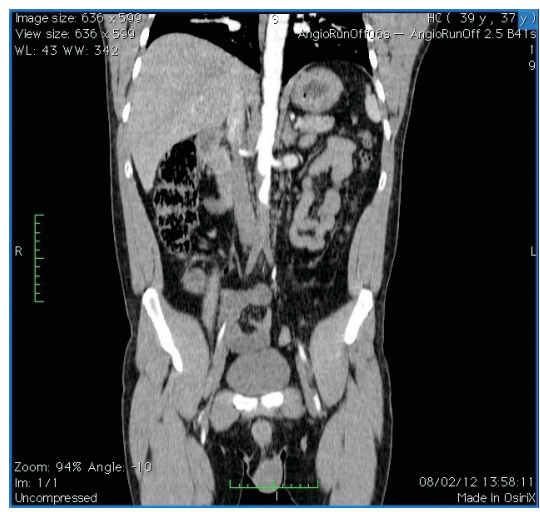

Figure 1. Coronal angiotomography slice showing occlusion of the infrarenal aorta.
During a late postoperative consultation, in March 2013, examination revaled multiple oral ulcers (Figure 2), genital ulcers (Figure 3) and scaly skin lesions (Figure 4). At this point a diagnostic hypothesis of Behcet's disease was ventured and the patient referred for rheumatological follow-up and put on colchicine, with remission of the lesions.

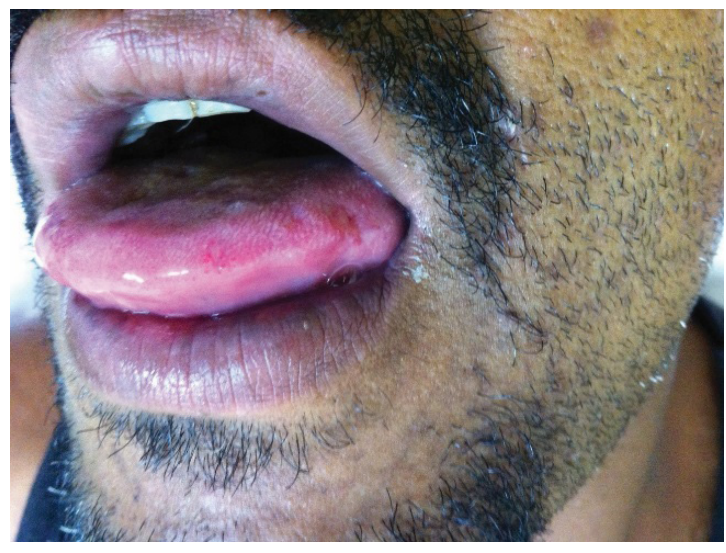

Figure 2. Oral ulcers.

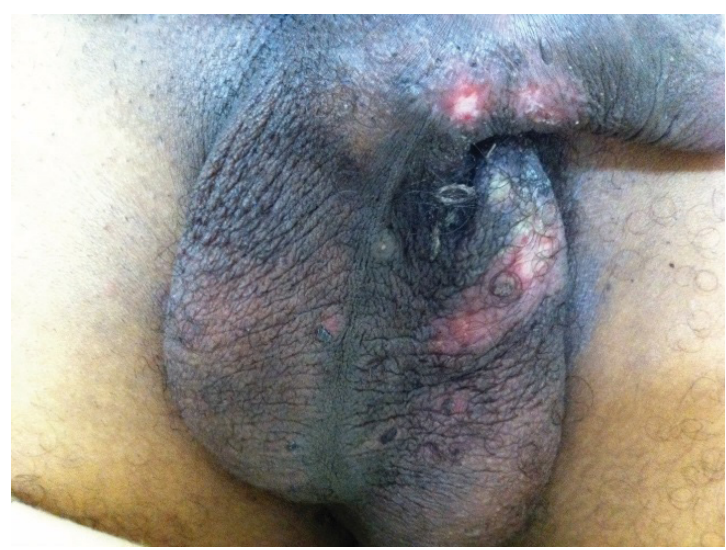

Figure 3. Genital ulcers.

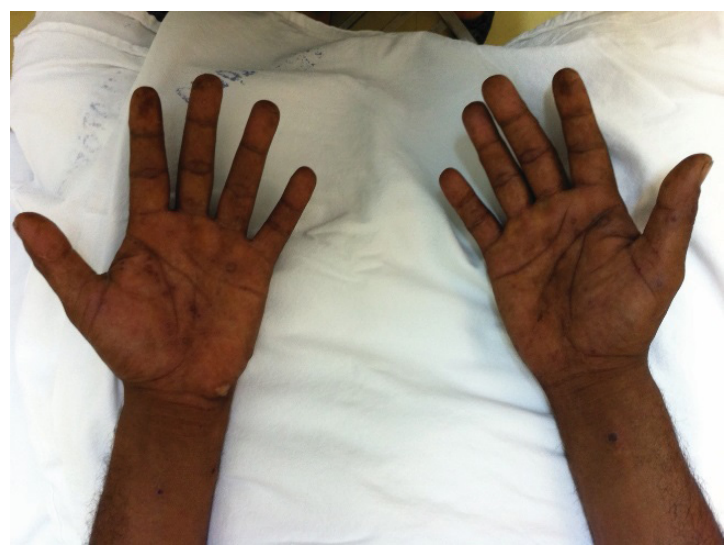

Figure 4. Scaly lesions on palms of hands. 


\section{DISCUSSION}

The pathogenesis of vascular thrombosis in Behcet's disease is not yet clear. Several studies have been conducted, but results are contradictory. Bacterial and viral infections, factor $\mathrm{V}$ Leiden mutations, presence of the HLA-B5 gene, mutations of the MEFV gene, hyperhomocysteinemia, vitamin B12 and folate deficiency, elevated von Willebrand factor and thrombomodulin have all been investigated in this respect. ${ }^{2,3,7} \mathrm{~A}$ hypothesis exists that there are diufferent coagulation disorders in different ethnic groups. What is currently known is that thrombosis in Behcet's disease is triggered by certain prothrombotic factors, but that its primary cause lies in factors related to the vessel wall. . $^{1,710}$ Shin-Seok Yang et al. observed elevated erythrocyte sedimentation rate and serum C-reactive protein in patients with Behcet's disease involving the arteries, and detected a correlation between increases in plasma $\mathrm{C}$-reactive protein and disease severity. ${ }^{5}$

In Behcet's disease, arterial involvement is less common than venous involvement, affecting from 1 to $7 \%$ of patients. ${ }^{5,7,8,10,14}$ Peripheral arterial lesions are observed in $2.6 \%$, according to Shin-Seok Yang et al. ${ }^{5}$ In $50 \%$ of cases, arterial injury and venous lesions are both present concomitantly. ${ }^{8,14}$ This is more common among male patients and smokers. ${ }^{7,8}$ Elevated serum endothelin-1 may also be detected. ${ }^{7}$

In general, the arterial component of the disease presents as a single lesion, but multiple lesions can also be seen. The symptoms of arterial occlusion may be intermittent claudication or critical ischemia, depending on the extent of the lesions and the time since onset. ${ }^{7}$

Vascular involvement of major vessels occurs in up to 35 to $39 \%$ of patients, ${ }^{5,14}$ typically involving pulmonary arteries, the aorta, the iliac arteries, femoral arteries or popliteal arteries. ${ }^{6,14}$ This is one of the few manifestations of the disease that are associated with systemic symptoms and laboratory evidence ${ }^{7}$ and, in general $(33 \%)$, occurs during the first 5 years after diagnosis. ${ }^{8}{ }^{8}$ However, in 7 to $30 \%$ of patients, vascular involvement has taken place before the disease is diagnosed clinically. ${ }^{6,8}$

In terms of treatment, the indications for surgery are the same as followed for peripheral arterial occlusive disease of other etiologies. However, it is necessary to conduct rigorous monitoring of both vascular and rheumatological aspects because of the increased risks of disease recurrence, of graft thrombosis and of anastomotic aneurysm. ${ }^{7}$ The best material for the arterial graft (whether prosthetic or venous) is still a subject of debate. Although venous grafts usually provide better patency over the long term, in Behcet's disease there is the possiblility that concomitant venous involvment could compromise the quality of the graft. ${ }^{5}$

Endovascular treatment is being used more and more often, when technicaly possible, because of the reduction in postoperative complications and the fact that these patients have a high likelihood of recurrence of arterial involvment., ${ }^{7,14}$

Several authors suggest adjuvant administration of corticosteroids or immunosuppressors postoperatively, and also anticoagulants or platelet antiaggregants, which may reduce the risk of graft occlusion ${ }^{1,5,7,14}$. Jayachandran and colleagues have suggested that pulse therapy with corticosteroids and cyclophosphamide is the best treatment option in cases of acute arterial involvment. ${ }^{11}$

\section{REFERENCES}

1. Kenneth J, Warrington TC, Leslie TC. Vasculitis and other arteriopathies. In: Cronenwett JL, editor. Rutherford's vascular surgery. Philadelphi: WB Saunders; 2010. p. 1156-1168.

2. Yurdakul S, Hamuryudan V, Yazici H. Behçet syndrome. Curr Opin Rheumatol. 2004;16(1):38-42. http://dx.doi.org/10.1097/00002281200401000-00008. PMid:14673387.

3. Treudler R, Orfanos CE, Zouboulis CC. Twenty-eight cases of juvenile-onset Adamantiades-Behçet disease in Germany. Dermatology. 1999;199(1):15-9. http://dx.doi.org/10.1159/000018197. PMid:10449951

4. Karincaoglu Y, Borlu M, Toker SC, et al. Demographic and clinical properties of juvenile-onset Behçet's disease: a controlled multicenter study. J Am Acad Dermatol. 2008;58(4):579-84. http://dx.doi. org/10.1016/j.jaad.2007.10.452. PMid:18045733.

5. Yang SS, Park KM, Park YJ, et al. Peripheral arterial involvement in Behcet's disease: an analysis of the results from a Korean referral center. Rheumatol Int. 2013;33(8):2101-8. http://dx.doi.org/10.1007/ s00296-013-2700-9. PMid:23417141.

6. Melikoglu M, Kural-Seyahi E, Tascilar K, Yazici H. The unique features of vasculitis in Behçet's syndrome. Clin Rev Allergy Immunol. 2008;35(1-2):40-6. http://dx.doi.org/10.1007/s12016-007-8064-8. PMid:18172779.

7. Calamia KT, Schirmer M, Melikoglu M. Major vessel involvement in Behçet disease. Curr Opin Rheumatol. 2005;17(1):1-8. http:// dx.doi.org/10.1097/01.bor.0000145520.76348.dd. PMid:15604898.

8. Sarica-Kucukoglu R, Akdag-Kose A, Kayaball M, et al. Vascular involvement in Behçet's disease: a retrospective analysis of 2319 cases. Int J Dermatol. 2006;45(8):919-21. http://dx.doi. org/10.1111/j.1365-4632.2006.02832.x. PMid:16911374.

9. Ames PRJ, Steuer A, Pap A, Denman AM. Thrombosis in Behçet's disease: a retrospective survey from a single UK centre. Rheumatology (Oxford). 2001;40(6):652-5. http://dx.doi.org/10.1093/ rheumatology/40.6.652. PMid:11426022.

10. Düzgün N, Ateş A, Aydintuğ OT, Demir O, Olmez U. Characteristics of vascular involvement in Behçet's disease. Scand J Rheumatol. 2006;35(1):65-8. http://dx.doi.org/10.1080/03009740500255761. PMid: 16467046

11. Jayachandran NV, Rajasekhar L, Chandrasekhara PK, Kanchinadham S, Narsimulu G. Multiple peripheral arterial and aortic aneurysms in 
Behcet's syndrome: a case report. Clin Rheumatol. 2008;27(2):265-7. http://dx.doi.org/10.1007/s10067-007-0713-z. PMid:17929077.

12. Kural-Seyahi E, Fresko I, Seyahi N, et al. The long-term mortality and morbidity of Behçet syndrome: a 2-decade outcome survey of 387 patients followed at a dedicated center. Medicine (Baltimore). 2003;82(1):60-76. http://dx.doi.org/10.1097/00005792-20030100000006. PMid:12544711.

13. Calamia KT, Wilson FC, Icen M, Crowson CS, Gabriel SE, Kremers $\mathrm{HM}$. Epidemiology and clinical characteristics of Behçet's disease in the US: a population-based study. Arthritis Rheum. 2009;61(5):6004. http://dx.doi.org/10.1002/art.24423. PMid:19405011.

14. RobenshtokE, Krause I. Arterial involvement in Behçet's disease--the search for new treatment strategies. Isr Med Assoc J. 2004;6(3):1623. PMid: 15055273.
Correspondence

Ana Bittencourt Detanico

Décima Primeira Avenida, 1029/1706 - Residencial Pontal das Brisas CEP: 74605-060 - Goiânia (GO), Brazil Tel.: +55 (62) 96505049 E-mail:ana.detanico@gmail.com

Author information

ABD - MD from Universidade Federal do Rio Grande do Sul (UFRGS) with training in General Surgery from Hospital Regional de Taguatinga (HRT)(ESCS); Resident physician of Vascular Surgery at Universidade Federal de Goiás (UFG)

$M L B$ - MD with training in General Surgery from Universidade Federal de Goiás (UFG); MSc and a PhD in Surgery from Faculdade de Medicina de Ribeirão Preto, Universidade de São Paulo (FMRP

/ USP); Board certified in Angiology and Vascular Surgery from Associação Médica Brasileira (AMB) and Sociedade Brasileira de Angiologia e Cirurgia Vascular (SBACV), and in Doppler Ultrasound and Angioradiology and Endovascular Surgery from AMB, SBACV, and Colégio Brasileiro de Radiologia (CBR).

LFF - MD with training in General Surgery from Universidade Federal de Goiás (UFG) and training in Vascular Surgery from Universidade Federal de Uberlândia (UFU); MSc in Parasitology from Universidade Federal de Goiás (UFG).

JRSS - MD from Universidade Federal de Goiás (UFG) with training in General Surgery from Hospital de Urgência de Goiania (HUGO) and training in Vascular Surgery from Universidade Federal de Goiás

(UFG); Resident of Endovascular Surgery and Radiointervention at Universidade Federal de Goiás (UFG) CPRC - MD from Universidade Federal de Goiás (UFG) with training in General Surgery from Hospital Geral de Goiânia (HGG); Resident of Vascular Surgery at Universidade Federal de Goiás (UFG).

Author contributions Conception and design: ABD, MLB Analysis and interpretation: $A B D, M L B$

Data collection: ABD, CPRC, JRSS Writing the article: $A B D, M L B$ Critical revision of the article: MLB, LFF Final approval of the article*: ABD, MLB, LFF, CPRC, JRSS Statistical analysis: N/A Overall responsibility: $A B D, M L B$

*All authors have read and approved of the final version of the article submitted to J Vasc Bras. 